\title{
The importance of adopting principles of corporate governance for the quality of internal audit
}

\author{
Fedaa Abd Almajid SABBAR \\ Al-Mustansiriyah University_ presidency university \\ Department of control and internal audit \\ Craiova University, Faculty of Economics and Administration, Craiova, Romania \\ fdaasabbar@yahoo.com \\ Zaid Yaseen Saud AL-DULAIMI \\ The Bucharest University of Economic Studies, Bucharest, Romania \\ zaidyaseen610@yahoo.com \\ Talib Ghadhban Yaseen ALALAWI \\ University ALMustansiriya, Baghdad, Iraq \\ Talebalawi@gmail.com \\ Arshed Makki RASHID \\ Al-Qadiseya University, Iraq \\ arshedmakey2017@gmail.com
}

\begin{abstract}
The topic of corporate governance and the quality of internal auditing have increased the importance in the light of fast economic changes. The financial systems of many of the world's largest companies face decreasing trust of the company's stakeholders and beneficiaries in the financial information they present. Iraq is considered one of the emerging countries in which the private sector suffers from the same problems as other international companies. At the same time, the indicators of financial and administrative corruption are increasing in the Iraqi economic and financial environments. The Iraqi environment requires the implementation of the principles of corporate governance, quality control and internal auditing. The aim of current study is to analyze the relationship and effects between the principles of corporate governance and the quality of the function of internal auditing in private companies in Iraq through statistical analysis of the survey data from a sample of internal audit managers and accountants. The recommendations presented aim to improve the quality of internal audit and support corporate governance to ensure the credibility of financial information disclosed in the financial statements by the executive departments in those companies, contributing to the decision-making process. The study reached several conclusions. The most important of these is that the effective and proper implementation of the principles of corporate governance in the private sector companies in Iraq will contribute to the improvement and development of the internal audit function in the company reflected positively on the performance, survival and continuity of corporate activity while safeguarding the interests of those involved.
\end{abstract}

Keywords: governance, principles, internal audit, quality, impact and relationship, control, accountability.

\section{Introduction}

In the last years, the importance of adopting corporate governance has increased due to the economic and financial crisis suffered by the main part of the world. Financial collapses of many major international multinationals have been analyzed in numerous academic and 
professional studies related to their causes, exposing the effects of administrative and financial corruption, weak control systems and internal audit in those companies. These led to the need to focus on the application of the principles of corporate governance and of the functions of control and internal audit in companies through the activation of accountability and oversight of the executive departments. In order to ensure the rights of all parties and beneficiaries, the financial information from the financial statements disclosed by those companies should provide a solid base for the decision-making process. Iraq is one of the emerging countries in which private companies suffer from administrative and financial corruption and the decline of confidence of the beneficiaries of the financial information disclosed by those companies. The function of control and internal audit in the companies of the administrative functions should be implemented through the activation of the oversight role, the application of corporate governance and the development and improvement of the quality control and internal audit functions. These are important to ensure the quality of financial information and the return of the confidence of the beneficiaries of that information. Hence, the importance of our study to shed light on the subject of corporate governance and the quality of internal auditing in the private sector companies in Iraq. We divided our study into several sections where the first sections presents the methodology of the study and the second section the previous studies. The third section is dedicated to the theoretical study and the fourth one presents the applied study. The fifth section includes the conclusions and recommendations of the study.

\section{Literature review}

The study of Zwilif \& Algoher (2007) focused on the analysis of the relationship between the internal control elements, the principles of corporate governance and the extent to which these elements contributed to these principles. One of the main findings of the study is that the success of corporate governance requires the application of these elements to the internal control elements.

Fatih \& Aishi (2008) are the authors of a study that highlighted the importance of corporate governance as an organizational framework to ensure the objective and integrity of financial information disclosed and to limit its use in a manner that misleads beneficiaries from the financial statements.

The study of Isaa (2008) focused on the factors determining the quality of internal auditing and its relationship with the quality of corporate governance. The main findings of the study were that raising and enhancing the quality of internal auditing would reflect positively on corporate governance.

The objective of the study of Rasha (2008) was to measure the impact of the quality of the internal audit on determining the fees of the external auditor.

Our current study is focused on the relationship and effects between the principles of corporate governance and the quality of internal audit and its reflection on financial information in the financial statements and return the confidence of the beneficiaries of that information in the Iraqi environment. 


\section{Methodology \\ Problem of the study}

Fast economic developments and globalization of the economy lead to the appearance of international multinational companies. The financial collapse of many of these companies in recent years has led to the urgent need to focus on the topics of corporate governance and the quality of internal audit in supporting governance in order to increase the confidence of the beneficiaries of financial information in the financial statements provided by those companies. These aspects contribute to the insurance of the continuity of these companies as well as their growth.

The study problem can be identified by answering the following question: Does the application of the principles of corporate governance contribute to the improvement of the quality of internal audit performance in the private sector companies in Iraq enhancing the credibility of the financial information disclosed by the company and the confidence of the beneficiary parties in this information?

\section{The importance of the study}

The importance of study is linked to the importance of corporate governance and quality of internal auditing in the Iraqi environment. The decline in trust in the performance of private sector companies is a result of administrative and financial corruption in the majority of the Iraqi companies. The confidence of the relevant beneficiaries of the financial information disclosed in the financial statements of those companies is very low. Our current study seeks to provide recommendations that improve the performance of the internal audit function in these companies by focusing on the adoption of the principles of corporate governance and their impact on improving the quality of the performance of the internal control and auditing function, which contributes to ensuring the credibility of the disclosed financial information. As a result, the interests of the parties connected to the company are protected and the success and continuity of the company are ensured.

\section{The aim of the study}

The aim of the study is to investigate the impact and role of corporate governance in improving the quality of internal audit performance in private sector companies in Iraq, thus contributing to the confidence of the beneficiaries in the financial information disclosed in the financial statements of these companies while supporting the decisionmaking process.

\section{The hypothesis of the study}

There is a statistically significant impact on the application of corporate governance principles in improving the quality of internal audit in Iraqi private companies.

\section{Results and discussions}

Theoretical framework

The concept of internal auditing - importance, standards and quality

The Arab Society of Accountants has defined internal auditing as an internal function of the company's management to reflect an independent internal activity for the establishment of administrative control, including accounting, to assess the compatibility of the system with 
what the requirements or to work on the best use of resources to achieve maximum productivity (Mohamed, 2012, p. 5).

Following the fast economic developments, the expansion of the activities of the companies, the increase in the number of international multinational companies and the expansion of their administrative, financial and accounting activities, there was an urgent and necessary need for continuous evaluation of the activity of these companies by specialists with experience in the activity of these companies. This can be provided by internal auditors through various services (Kamal, 2009, p. 25): preventive services (providing assurances of adequate protection of assets), valuation services (internal audit assesses and evaluates the effectiveness and procedures of internal control systems and the extent to which they comply with administrative policies), development and improvement services (proposing the necessary improvements to the systems within the companies), and control and protection services (preventing administrative policy from deviation from actual application).

The internal audit standards are the rules and principles that govern the audit process and are the means of assess its performance. The internal auditors set the basic standards for internal auditing: independence and implementation of the auditor's work, professional qualification and management of internal audit, range and scope of work.

Professional auditing has increased the quality of internal audit in recent years after the financial collapse and the spread of administrative and financial corruption of many major international companies. Internal and external auditors can provide early warning in the prediction of financial failures and detect cases of corruption. The quality of the internal audit defined by Nawal, (2010, p. 4) as: "The internal auditors have assumed the responsibilities entrusted to them with a high degree of efficiency by achieving the objectives of the internal" (Nawal, 2010, p. 4). The assessment of auditors is performed through periodic and express opinion about them for the purpose of improving and developing them to achieve the highest administrative efficiency; periodic evaluation of financial and accounting policies and all matters related to them; periodic evaluation of their compliance to the plan.

The quality of internal audit can be determined through the following: (Rasha, 2008, p. 56) the objectivity and independence of the internal auditors, professional care through the efficiency in the evaluation of the administrative policies and operational procedures, appropriate number of auditors.

Corporate Governance (concept, recognition, importance, principles, impact and relationship with quality)

The concept of corporate governance has become a necessity in many developed and developing countries in recent years following the economic and financial collapse of many major international companies. The definition of the Institute of Internal Auditors for Internal Audit is one of the most recent definitions, which shows that internal audit is an objective, independent insurance activity designed to add value and improve the organization's operations. The organization is assisted in achieving its objectives through the organizational and disciplined approach to assess and improve the effectiveness of risk management, oversight and corporate governance (AII, 2004).

This definition refers to developments in the internal audit function in terms of scope and responsibilities and to the role of internal audit in increasing the value and 
improving the performance of the company's operations. It reflects the role of internal audit in risk management, in evaluation of the internal control system and in governance support (Anderson, 2003, p. 106). The role of the internal audit includes providing objective assurance regarding the internal control and risk management system and the company's compliance with the standards of governance, as well as other modern requirements. Therefore, the internal audit function according to the modern concept is the most important pillar and regulatory mechanisms in the field of corporate governance starting from the Board of Directors and executive management.

The importance of corporate governance is to optimize the use of resources, maximize the value of the company and enhance its competitiveness in the markets. This is reflected positively on the attraction of local and international sources of finance, ensuring the integrity of management and fulfilling its obligations in order to ensure that the company achieves its objectives.

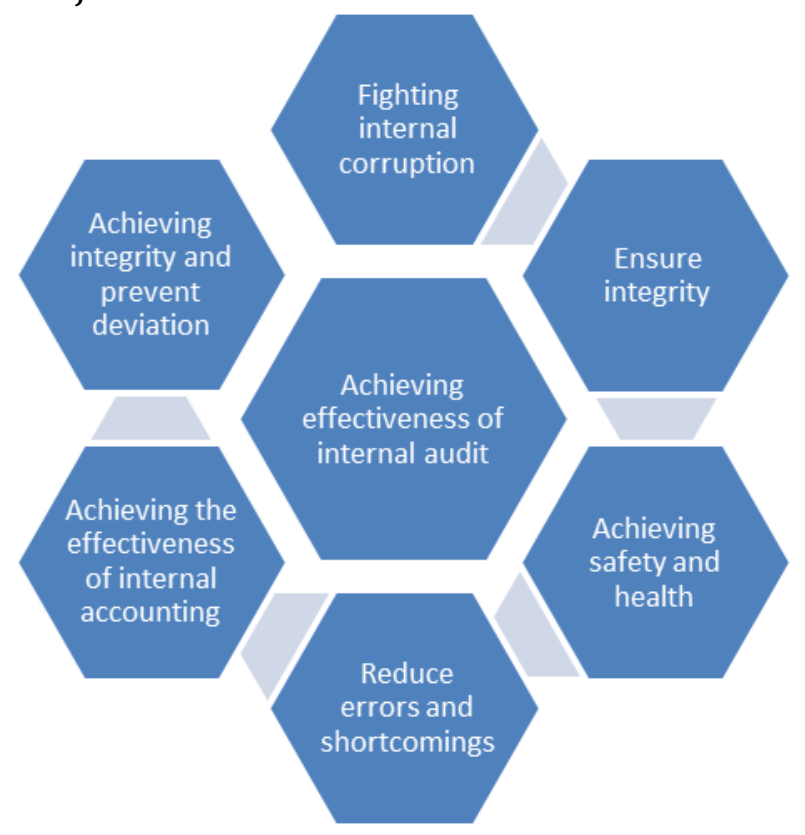

Figure 1. [Importance of corporate governance]

Source: Mahsen,2005:58

According to studies carried out by specialized organizations such as OECD, corporate governance is based on a set of principles detailed in the paragraphs below.

Disclosure and transparency means publication of financial information to users and beneficiaries of the financial statements, such as shareholders, investors and other beneficiaries for the purpose of rationalizing their decisions. Such disclosure must be fair, objective and impartial to a particular party. It should not contain misleading information and be submitted in a timely manner to all users of that financial information (Fawzy, 2003, p. 5)

Accountability means that the company's management, internal audit and external audit committee and external auditor are subject to control and accountability (Hermanson \& Rittenerg, 2003, p. 30).

Responsibility represents the company's commitment to its duties and moral obligations to the society, which are supporting the employees of the company, providing 
the best services to customers, with the lowest impact on the environment through the principle of reward, punishment and accountability of the company's executive the management (Gill, 2003, p. 66).

Justice means the company's commitment to the standards of justice by respecting the rights of the beneficiaries and interests of the company in addition to the distribution of duties and responsibilities equally to its employees, the equal distribution of incentives and rewards, preventing the exploitation of senior executive positions in obtaining illegal privileges (O'Sullivan, 2003, p. 12).

Independence is considered one of the most important standards to support the conflict of interest in the company. It must provide control, follow-up and full independence in the work of the external audit committee and of the external internal auditors in exposing the parties that pressures the executive management to provide incorrect or misleading information (Jane, 2003, p: 242).

The principle of laws and systems means issuing laws, regulations and instructions that support the requirements of applying corporate governance. These are the laws of companies, capital markets, banks and the profession of external and internal auditing in a manner that guarantees the rights of shareholders, investors and employees of the company. In addition, the shareholders of the company are granted the right to vote (Zingales, 1997, p. 2).

There is a relationship between the principles of corporate governance and the quality of internal auditing in these companies, especially after the economic developments and changes in recent years. The financial failures of many international companies has increased the importance and expansion of the role of the internal audit function with increasing the obligations and requirements imposed by law (Sarbanes -oxely) of year 2002. This law aims to improve the quality of corporate governance by obliging the management of companies to document and evaluate the report on the effectiveness of internal control. At the same time, the external auditor of the company is required to evaluate the procedures of corporate management. Assessing the internal control as the internal audit function plays an active role in supporting and implementing the basic principles of corporate governance. The internal audit performance of these companies has to be developed by implementing their standards in accordance with the requirements of corporate governance. The Institute of Internal Auditors (AII) has recently issued standards for internal audit activity. These standards, when adopted and implemented, contribute to the provision of guidance and evidence to assess the performance and quality of internal audit, which is one of the means of supporting and attributing to corporate governance. These standards include Standard No. 2100 and 2130 of the Group II standards on corporate governance. Internal audit activity supports the corporate governance processes by contributing to the assessment and improvement of the governance process by verifying and reached values and the objectives. The departments are ready and able to disclose that their interactions, actions and decisions are in line with the objectives set agreed upon, as well as monitoring the process of achieving the objectives.

\section{Applied Study}

The following form will be adopted in the applied study: 


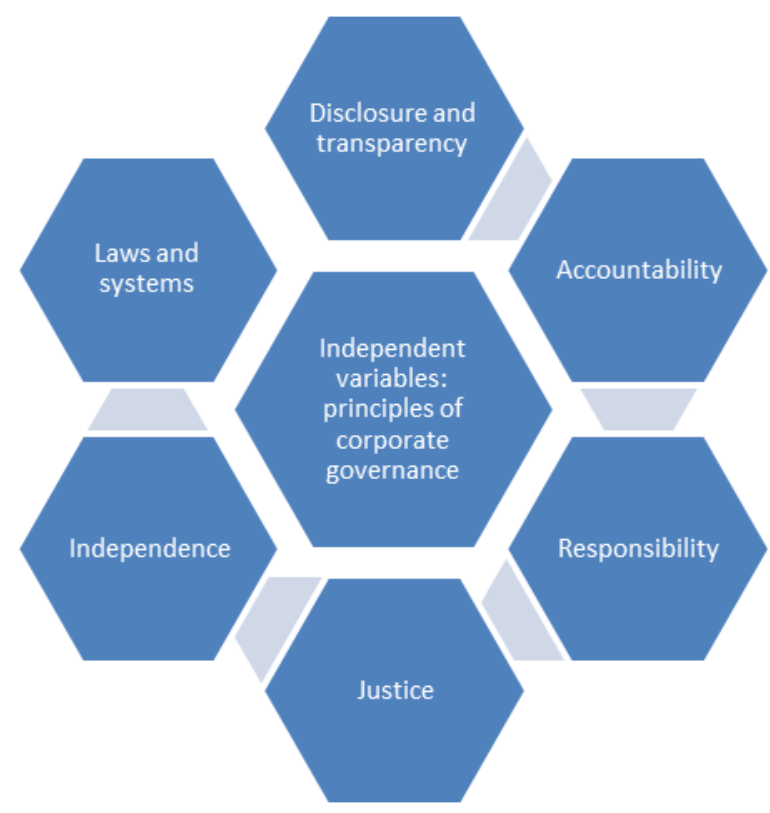

PICBE $\mid 1095$

Figure 2. [Independent variables]

Source: prepared by the researchers.

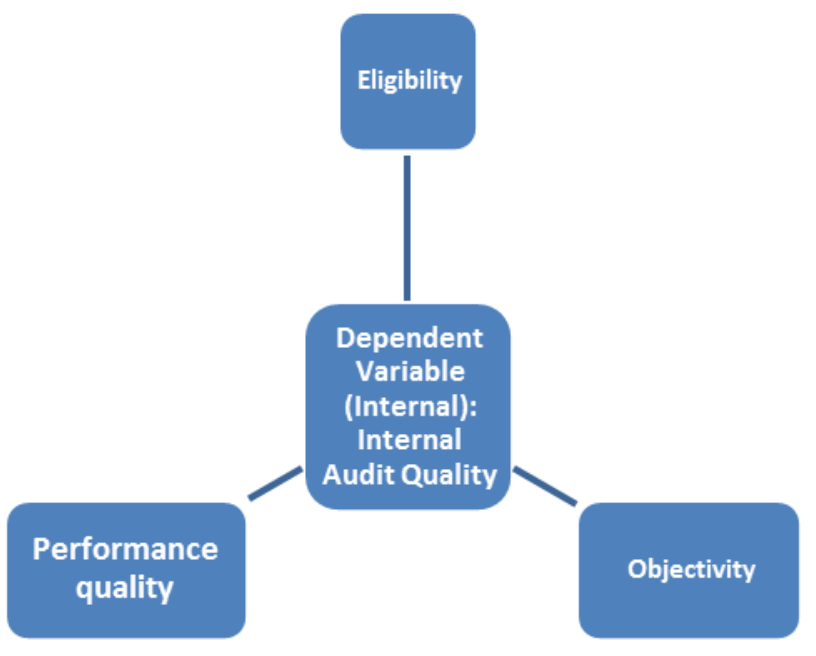

Figure 3. [Dependent variable]

Source: prepared by the researchers.

\section{Study population and sample}

The sample is chosen from Iraqi industrial companies listed on the Iraqi stock market. The sample includes ten companies with important role in the national economy of Iraq. Fifty questionnaires were distributed to the managers of the internal audit department, financial managers, accountants and auditors, in these companies, and the statistical analysis program (spss) was used for the data processing. The linear regression analysis was used to identify and measure the impact of the principles of corporate governance on the quality of 
internal auditing. We relied on three levels (weak, average, high) to comment on the arithmetic mean of the variables, according to the following equation:

The length of the class = (the upper limit of the alternative - the minimum of the alternative) / the number of levels

(5- 1$) / 3=1.33$

Thus, the levels are as follows: weak, from 1 to less than 2.33, average, from 2.33 to less than 3.66 and high, from 3.66 to 5 .

Table 1. The results of the analysis of the multiple regression of the principles of corporate governance and quality of internal audit

\begin{tabular}{|c|c|c|c|c|c|c|c|}
\hline \multicolumn{2}{|c|}{\begin{tabular}{|l|} 
B \\
\end{tabular}} & Sig & sig & $\mathbf{F}$ & $\mathbf{R 2}$ & $\mathbf{R}$ & \multirow{2}{*}{$\begin{array}{l}\text { Dependent } \\
\text { variable }\end{array}$} \\
\hline \multicolumn{2}{|c|}{ regression coefficient } & $\begin{array}{l}\text { level of } \\
\text { significance }\end{array}$ & $\begin{array}{l}\text { level of } \\
\text { significance }\end{array}$ & calculated & $\begin{array}{l}\text { coefficient of } \\
\text { determination }\end{array}$ & $\begin{array}{l}\text { correlation } \\
\text { coefficient }\end{array}$ & \\
\hline 0.256 & 0.000 & 0.000 & & 2.244 & 0.411 & 0.634 & $\begin{array}{l}\text { Internal } \\
\text { Audit } \\
\text { Ouality }\end{array}$ \\
\hline 0.147 & 0.000 & 0.000 & & & & & \\
\hline 0.130 & 0.000 & 0.000 & & & & & \\
\hline 0.234 & 0.000 & 0.000 & & & & & \\
\hline 0.141 & 0.000 & 0.000 & & & & & \\
\hline 0.245 & 0.000 & 0.000 & & & & & \\
\hline
\end{tabular}

Source: Authors' own research.

It is clear from the data in Table (1) above that there is a statistically significant effect of all the principles of governance on the quality of internal auditing, where the coefficient of correlation is 0.634 and the R2 identification factor is 0.41 . This means that $41 \%$ of the changes in the quality of the internal audit result from the change in principles. The total value of the calculated $\mathrm{F}$ is 2.24 is a function at a significant level of 0.05 .

Table 2. Arithmetical averages - disclosure and transparency variables

\begin{tabular}{|l|l|l|r|l|}
\hline Details & $\begin{array}{l}\text { Arithmetic } \\
\text { mean }\end{array}$ & $\begin{array}{l}\text { Standard } \\
\text { deviation }\end{array}$ & $\begin{array}{r}\text { Level of } \\
\text { importance }\end{array}$ & Ranking \\
\hline $\begin{array}{l}\text { Important information is disclosed in a fair and } \\
\text { honest manner. }\end{array}$ & 4.040344 & 0.61347 & high & 1 \\
\hline $\begin{array}{l}\text { Important information is disclosed with } \\
\text { objectivity, honesty and integrity. }\end{array}$ & 3.928624 & 0.7080794 & high & 2 \\
\hline $\begin{array}{l}\text { Important information is disclosed in a timely } \\
\text { manner and without delay. }\end{array}$ & 3.894226 & 1.005284 & 3 \\
\hline $\begin{array}{l}\text { Information on ownership of the majority of shares } \\
\text { in the company is provided. }\end{array}$ & 3.558968 & 1.108282 & average & 4 \\
\hline $\begin{array}{l}\text { Information on members of the Board of Directors } \\
\text { is provided. }\end{array}$ & 3.309657 & 1.116906 & average & 6 \\
\hline Information on executive managers is provided & 3.41285 & 1.123276 & average & 5 \\
\hline General average & 3.690778 & 0.945896 & high & \\
\hline
\end{tabular}

Source: Authors' own research.

The analysis of the results in Table (2) above reveals that the relative importance levels of the variable of disclosure and transparency range between the high and the average level. Their mean scores are between 4.040344 and 3.309657. This result indicates 
that there is a high impact of the principle of disclosure and transparency in the quality of the internal audit in the sample of Iraqi private companies according to the opinion of the sample members. The mean of their answers is 3.690778 and the standard deviation reached 0.945896 . This low value indicates that there are no differences in the answers of the sample members.

Table 3. Arithmetical averages and standard deviations of the accountability variable

\begin{tabular}{|l|l|l|l|l|}
\hline Details & $\begin{array}{l}\text { Arithmetic } \\
\text { mean }\end{array}$ & $\begin{array}{l}\text { Standard } \\
\text { deviation }\end{array}$ & $\begin{array}{l}\text { Level } \\
\text { of } \\
\text { impor } \\
\text { tance }\end{array}$ & Ranking \\
\hline The work of the executive management is evaluated. & 3.791032 & 0.9447886 & high & 2 \\
\hline $\begin{array}{l}\text { The tasks to ensure that the work is done strictly by the } \\
\text { rest of the company's staff are carried out. }\end{array}$ & 3.928624 & 0.7080791 & high & 1 \\
\hline Periodic reports are provided on business results. & 3.653538 & 0.986762 & high & 3 \\
\hline The success of periodic reports is assessed. & 3.627767 & 0.8442308 & high & 4 \\
\hline \multicolumn{1}{|l|}{ General average } & 3.750166 & 0.870926 & high & \\
\hline
\end{tabular}

Source: Authors' own research

The analysis of the results in Table (3) shows that all the levels of importance of the accountability variable were of a high level in terms of their average arithmetic mean (3.928624 - 3.627767). This indicates that there is a high impact of the principle of accountability in the quality of internal auditing in the sample of industrial companies (3.750166). The standard deviation is 0.870926 .

Table 4. Arithmetical averages and standard deviations of the variable of responsibility

\begin{tabular}{|l|l|l|l|l|}
\hline \multicolumn{1}{|c|}{ Details } & $\begin{array}{l}\text { Arithmeti } \\
\text { c mean }\end{array}$ & $\begin{array}{l}\text { Standard } \\
\text { deviation }\end{array}$ & $\begin{array}{l}\text { Level of } \\
\text { importanc } \\
\text { e }\end{array}$ & Ranking \\
\hline $\begin{array}{l}\text { There is an emphasis on the ethical message of the } \\
\text { company in society. }\end{array}$ & 3.756634 & 0.921102 & high & 4 \\
\hline $\begin{array}{l}\text { Managers are committed to their responsibilities towards } \\
\text { the community. }\end{array}$ & 3.894226 & 0.85946 & high & 1 \\
\hline Commitment to environmental protection is complied with & 3.386978 & 1.030078 & average & 5 \\
\hline $\begin{array}{l}\text { Obligations to employees and to improve services provided } \\
\text { to them are complied with. }\end{array}$ & $\begin{array}{l}3.773881 \\
21\end{array}$ & $\begin{array}{l}0.773876 \\
6\end{array}$ & high & 3 \\
\hline $\begin{array}{l}\text { Commitment to the shareholders is met and appropriate } \\
\text { returns are made to them. }\end{array}$ & 3.782408 & 1.05252 & high & 2 \\
\hline General average & 3.718806 & 0.907774 & high & \\
\hline
\end{tabular}

The analysis of the results in Table (4) above shows that the levels of importance of the responsibility variables ranged between high and average levels and their average arithmetic mean is between 3.894226 and 3.756634. The general result indicates that there is a high level of impact on the quality of internal audit in the sample companies with an average of 3.7188 and a deviation of 0.9077 , indicating the consensus of the sample.

Table 5. Arithmetical averages and standard deviations of the variable of justice

\begin{tabular}{|l|l|l|l|l|}
\hline Details & $\begin{array}{l}\text { Arithmeti } \\
\text { c mean }\end{array}$ & $\begin{array}{l}\text { Standard } \\
\text { deviation }\end{array}$ & $\begin{array}{l}\text { Level } \\
\text { importance }\end{array}$ & Ranking \\
\hline
\end{tabular}




\begin{tabular}{|l|l|l|l|l|}
\hline $\begin{array}{l}\text { Respect the rights of various groups of } \\
\text { stakeholders in the company. }\end{array}$ & 3.78240 & 0.883078 & high & 3 \\
\hline $\begin{array}{l}\text { Distribution of responsibilities and duties among } \\
\text { employees in the company according to the } \\
\text { principles of justice and equality. }\end{array}$ & 3.92 & 0.814184 & high & 1 \\
\hline $\begin{array}{l}\text { Shareholders are treated according to the } \\
\text { principles of equity. }\end{array}$ & 3.799656 & 1.019396 & high & 2 \\
\hline $\begin{array}{l}\text { The company's profits are distributed according } \\
\text { to the principles of equity. }\end{array}$ & 3.66206 & 0.984998 & high & 4 \\
\hline General average & 3.791032 & 0.925414 & high & Pource: Authors' own research \\
\hline
\end{tabular}

The analysis in the results of Table (5) shows that all the levels of importance of the justice variable have a high level of influence and their mean averages are between 3.92-3.66206. This result indicates a high level of impact on the principle of justice in the quality of internal audit in the sample of industrial companies in Iraq.

Table 6. Arithmetical averages and standard deviations of the variable of independence

\begin{tabular}{|l|l|l|l|l|}
\hline Details & $\begin{array}{l}\text { Arithmetic } \\
\text { mean }\end{array}$ & $\begin{array}{l}\text { Standard } \\
\text { deviation }\end{array}$ & $\begin{array}{l}\text { Level of } \\
\text { importanc } \\
\text { e }\end{array}$ & Ranking \\
\hline $\begin{array}{l}\text { The auditor is not exposed to any effects in the } \\
\text { activity }\end{array}$ & 3.42137 & 1.203636 & average & 4 \\
\hline $\begin{array}{l}\text { The auditor performs the activity fairly and } \\
\text { impartially from any bias and conflict of interest. }\end{array}$ & 3.54172 & 1.094758 & average & 1 \\
\hline $\begin{array}{l}\text { Employees of the company have intellectual } \\
\text { independence in all matters related to their activity. }\end{array}$ & 3.24948 & 1.204224 & average & 5 \\
\hline $\begin{array}{l}\text { Employees avoid relationships that lose them } \\
\text { objectivity and expose them to the domination of } \\
\text { other parties. }\end{array}$ & 3.498796 & 1.236564 & average & 2 \\
\hline $\begin{array}{l}\text { The existence of relationships lacking objectivity } \\
\text { and independence when doing business. }\end{array}$ & 2.501548 & 1.083684 & average & 3 \\
\hline General average & 3.242526 & 1.164534 & average & \\
\hline
\end{tabular}

The analysis of the results in Table (6) shows that all the levels of importance of the independence variable were of the average level of effect and their mean scores were between 3.54172 and 3.24948. This result indicates an average level of effect on the independence of the quality of the internal audit of the sample of Iraqi industrial companies. 
Table 7. Arithmetical averages and standard deviations of the variable of laws and regulations

\begin{tabular}{|l|l|l|l|l|}
\hline Details & $\begin{array}{l}\text { Arithmeti } \\
\text { c mean }\end{array}$ & $\begin{array}{l}\text { Standard } \\
\text { deviation }\end{array}$ & $\begin{array}{l}\text { Level of } \\
\text { importan } \\
\text { ce }\end{array}$ & $\begin{array}{l}\text { Ranki } \\
\text { ng }\end{array}$ \\
\hline $\begin{array}{l}\text { The company meets the requirements of relevant } \\
\text { laws and regulations in the conduct of its business. }\end{array}$ & 3.756634 & $\begin{array}{l}0.921141 \\
2\end{array}$ & high & 3 \\
\hline $\begin{array}{l}\text { There are laws and regulations that clarify } \\
\text { shareholder rights and duties such as the right to } \\
\text { vote and the election of members of the Board of } \\
\text { Directors. }\end{array}$ & 4.12629 & 0.98833 & high & 1 \\
\hline $\begin{array}{l}\text { The rights of the society to the company and its } \\
\text { obligations towards it are clarified. }\end{array}$ & 3.748108 & 0.01886 & high & 4 \\
\hline $\begin{array}{l}\text { Compliance with applicable laws and legal } \\
\text { regulations shall be observed. }\end{array}$ & 3.876978 & 1.344756 & high & 2 \\
\hline \multicolumn{1}{|c|}{ General average } & 3.876978 & 1.044582 & high & \\
\hline
\end{tabular}

The analysis of the results in Table (7) shows that all levels of importance of the variable of laws and regulations were of the highest level of influence and their mean averages were between 4.1229 and 3.748108. This general result indicates that there is a high level of impact of the laws and regulations on the quality of internal audit in a sample of private companies in Iraq.

\section{Conclusions}

After reviewing the theoretical study and analyzing the results of the field study, our study reached the conclusions detailed in the paragraphs below.

The effective and proper implementation of the principles of corporate governance in the Iraqi private sector companies will contribute to improving and developing the internal audit function and increasing its performance while activating its role in the framework of governance mechanisms through internal auditing and auditing of companies.

The commitment of the Internal Audit Section in the private sector companies in Iraq to work in accordance with the International Standards of Internal Auditing will add good skills in the performance of the internal auditor, which positively reflects on the improvement and development of the quality performance and efficiency in all the activities, especially the advisory services.

The control role is performed by internal audit through functions in the framework of corporate governance, which include providing information to management at all levels and assessing the internal control system and the commitment of companies to the principles of corporate governance.

\section{Recommendations}

In the light of the conclusions reached, the study makes the recommendations detailed in the paragraphs below:

The need for the private sector companies in Iraq to adhere to the effective and proper implementation of the principles of corporate governance, which will positively 
reflect on the improvement of the quality of the performance of the internal control and audit departments in these companies.

Issuing laws, regulations and instructions to provide the necessary legal environment for the effective application of corporate governance principles that support the quality of the performance of internal auditing in the private sector companies in Iraq.

Work on developing the knowledge and professional capacities of the internal auditor in companies on a continuous basis in order to be able to keep abreast of developments and changes in the economic and professional environment and perform the tasks efficiently and effectively.

Conducting professional and scientific studies necessary to understand the principles of corporate governance by internal auditing as one of the pillars and key elements to ensure the success of the process of supervision and internal audit.

\section{References}

Anderson, U. (2003). Assurance and consulting services. Research opportunities in internal auditing, 1, 1-23.

O'Sullivan, M. (2003) Employees and Corporate Governance, in P. K. Cornelius and B.

Kogut (eds.) Corporate Governance and Capital Flows in a Global Economy, New York:

Oxford University Press.

Fawzy, S. (2003). Assessment of corporate governance in Egypt. The Egyptian Centre for Economic Studies Working Paper, 82.

Fatih, D. \& Aishi, B. (2008). Corporate governance as a tool to ensure the reliability of financial information and accounting systems. Article presented to the third scientific conference of the faculty economics university, Jordan, 55.

Gill, A. (2008). Corporate governance as social responsibility: A research agenda. Berkeley J. Int'l L., 26, 452.

Hermanson, D. R., \& Rittenberg, L. E. (2003). Internal audit and organizational governance. Research opportunities in internal auditing, 1, 25-71.

Institute of internal auditors IIA (2004). Code of ethics and standards for professional practice of internal auditing available.

Isaa, K. (2008). Factors determining the quality of the internal audit function in improving the quality of corporate governance. Journal of the Commerce for Scientific Research, Alaskndria University, 1, 1-57.

Mutchler, J. F. (2003). Independence and objectivity: a framework for research opportunities in internal auditing. Research Opportunities in Internal Auditing, 231268.

Mahsen, A. (2005). Corporate governance. Arab Nile Group, Egypt, 58.

Mohammed, F. (2012). Internal auditing and its relationship to quality control in economic institutions get ISO certified. Conference University Ub Skikda, 20, 5.

Nawal, M. (2010). Analysis of factors affecting the quality of external audit. Master thesis. University of Qadisiyah, Faculty of Administration and Economics, Iraq, 4.

Kamal, N. (2009). The extent to which internal auditing standards are applied in Islamic banks. Master thesis, 25.

Rasha, A. (2008). The impact of the quality of the internal audit on determining the fees of the external auditor. Master thesis. Faculty of Administration and Economics, 56. 
Zingales, L. (1997). Corporate Governance. NEBR Working.

Zwilif, A. \& Aljoher, K. (2007). The role of compliance with internal control in supporting institutional controls. Journal of Research on Human Studies. University of UtSkikda, 1, Jordan, 56.

PICBE $\mid 1101$ 